\title{
\#LivingOffTips: Reframing food system labor through tipped workers' narratives of subminimum wage exploitation
}

\author{
Kathleen P. Hunt * \\ Iowa State University
}

\begin{abstract}
Submitted September 23, 2015 / Revised December 12, 2015, and January 26, 2016 /
Accepted January 27, 2016 / Published online April 4, 2016

Citation: Hunt, K. P. (2016). \#LivingOffTips: Reframing food system labor through tipped workers' narratives of subminimum wage exploitation. Journal of Agriculture, Food Systems, and Community Development, 6(2), 165-177. http://dx.doi.org/10.5304/jafscd.2016.062.021
\end{abstract}

Copyright (C) 2016 by New Leaf Associates, Inc.

\begin{abstract}
Agrifood movement literature largely represents food system labor through images, descriptions, and depictions of farm workers and other agriculture-related labor, such as slaughtering and meatpacking. Although engaging in a holistic dialogue that considers the continuum of labor abuse across the food system may be a difficult task, privileging production-oriented food system labor reinforces what Guthman (2014) calls an "agrarian imaginary." Such narrow representations can marginalize the food system workers whom modern consumers are most likely to encounter: restaurant staff that prepare and serve food. Tipped workers' subminimum wage is subsidized by the good graces customers; staff have little access to health benefits or sick days; female
\end{abstract}

* Kathleen P. Hunt, Assistant Professor of Agricultural Communication, Department of Agricultural Education \& Studies, Iowa State University; 206D Curtiss Hall; Ames, Iowa 50011 USA; kphunt@iastate.edu restaurant staff are subject to sexual harassment, abuse, and even assault. Through the Restaurant Opportunities Centers United (ROC), tipped workers are engaging in active resistance through advocacy and online/social media campaigns. Stories of tipped worker exploitation submitted to the ROC \#LivingOffTips online forum are examined through qualitative analysis. Tipped workers' narratives frame the risks of tipped labor exploitation, define tips as an issue of wage inequality, and characterize the essential role played by wait staff, thereby encouraging a reconsideration of food system labor by the alternative food movement. By narrativizing their experience of the subminimum wage, tipped workers not only make restaurant labor abuse more visible, they strategically frame their work as legitimate food system labor.

\section{Keywords}

restaurant labor, subminimum wage, food justice, framing, narratives 


\section{Introduction}

From growing and picking produce to managing and slaughtering livestock, from food manufacture to food transport, from stocking store shelves to serving fast food, the modern industrial food system runs on labor from farm to table. Foodrelated industries, including those involved in the growing and harvesting, processing, stocking, preparation, and serving of foodstuffs, comprise the largest sector of the U.S. economy, accounting for nearly five percent of the GDP ${ }^{1}$ (U.S. Department of Agriculture, Economic Research Service, n.d.). Despite the productivity of this sector, workers across the food system use public assistance such as food stamps (SNAP) twice as much as the rest of the U.S. workforce (Food Chain Workers Alliance, 2012). Indeed, labor insecurity and inequality exists on a continuum across the global industrial food system.

Critiques of food system labor have largely tended to focus on production-oriented workers, such as farm laborers or meat packers and processors (Alkon \& Agyeman, 2011; Gottlieb \& Joshi, 2010; Gray, 2014; Weber, 2009). As Guthman (2014) has suggested, this can indicate a latent privileging of an agrarian mythos that elevates an idyllic image of American agriculture. However, in limiting the scope of food system labor reform to those who represent more traditional forms of food work (such as farmers) or "conventional food chain workers" (Sbicca, 2015, p. 675), food system researchers, agrifood advocates, and food justice activists risk marginalizing the food-related workforce that consumers are more likely to interact with: tipped restaurant staff.

The restaurant industry accounts for some of the fastest U.S. job growth (Coughlan, 2014), employing nearly eight percent of the workforce. Yet employees in this sector experience difficult working conditions, high turnover, and historically stagnant wages (Jayaraman, 2013). In particular, restaurant workers experience poverty at nearly three times the rate of any other workforce. Con-

\footnotetext{
${ }^{1}$ In dollars, agriculture and food-related industries accounted for nearly US $\$ 835$ billion of the U.S. domestic gross domestic product (GDP) in 2014 (USDA Economic Research Service, n.d.).
}

trary to popular stereotypes, the average tipped restaurant worker is most likely to be female, over 30, with children (ROC, 2015). While they struggle with personal conditions of food hardship, unsafe working conditions, and low wages, these workers nevertheless provide essential labor that keeps the food system functioning.

Resistance to these conditions has been developing since employees of Windows on the World, the fine-dining restaurant atop the World Trade Center, waged a strike in 2002 (Jayaraman, 2013). Through organizations such as Restaurant Opportunities Centers United (ROC), restaurant workers have continued active resistance through guerilla-style peer-to-peer research, advocacy and leadership training, and national public campaigns. Since 2013, ROC has led campaigns, from Washington, D.C., to Los Angeles, to raise the subminimum wage and to curb other labor abuses affecting food industry workers, such as wage theft and discrimination. With 10 chapters, ROC has continued to organize restaurant industry reform campaigns across the U.S., establishing the 1 Fair Wage campaign to increase the restaurant minimum wage and eliminate dependence on tips for server income. In addition to public rallies, 1 Fair Wage facilitates \#LivingOffTips, a publicly accessible web page for sharing stories of restaurant labor and subminimum wage abuse, and of need for food system reform.

The subject of this analysis is the struggle of restaurant workers against an exploitative tippedwage system. By sharing their stories of \#LivingOffTips, these workers make their wage exploitation visible to audiences that perpetuate and participate in the subminimum wage, including the public, other tipped workers, legislators, and agrifood researchers and advocates, framing their position as food system labor and the need for subminimum wage reform.

\section{Labor and the AgriFood Movement}

Food and labor justice groups have long fought for food workers' rights, from the historic United Farm Workers strike of the 1960s to the Coalition of Immokalee Workers' public demonstrations against Yum! Brands. The issues these laborers face, such as low wages, unsafe work conditions, as 
well as racial and gender discrimination, are indeed important, and continue to impact the marginalized groups that sustain our food system. Tipped restaurant workers endure similar hardships: the lowest and most historically stagnant wages, harsh work environments, and risk of sexual violence.

Tipped restaurant staff are paid what is known as a subminimum wage. Though some states may have higher minimums, the average subminimum hourly wage is US $\$ 2.13$. Restaurant workers receive tips with the expectation (indeed, a federal mandate) that tips combined with the direct hourly wage "at least" equals the federal minimum wage (U.S. Department of Labor, n.d.). Working 40 hours per week, a worker paid the federal minimum wage (US $\$ 7.25$ per hour) earns approximately US $\$ 16,000$ per year; a restaurant server working 40 hours per week would have to make up more than US $\$ 10,000$ in tips to equal the annual earnings of their untipped counterpart. About half of all food and beverage servers and related workers (including those in service, prep, cleaning, and customer service positions in the restaurant industry) were employed part-time in 2012 (BLS, 2014). Furthermore, because of employees' part-time status, restaurant employers are able to maintain a workforce just below the federal requirements for health insurance benefits; many workers, including servers and kitchen staff, are thus forced to work while ill. Indeed, there are no federal or state requirements for restaurants to provide tipped workers paid sick days; many food industry employees report not even having the opportunity for an unpaid sick day (Jayaraman, 2013, p. 53). Finally, although female staff make up only about 7 percent of the restaurant workforce, they are extremely vulnerable to sexual harassment; nearly 37 percent of all sexual harassment complaints received in 2011 by the Equal Employment Opportunity Commission were filed by female restaurant workers (Jayaraman, 2013, p. 142).

Although it is likely an unintentional oversight, the agrifood movement ${ }^{2}$ has been slow to engage

\footnotetext{
2 "Agrifood" is purposefully used in this analysis to denote the scope and transformative potential (Fairbairn, 2012) of the food movement and mission referred to throughout the essay. While various terms abound in the literature (food movement,
}

the significant and pervasive exploitation of labor in the restaurant industry. Much of the critical public and academic scholarship on agrifood politics critiques primarily the modern corporatized food system (Besky \& Brown, 2015; Fairbairn, 2012; Sbicca, 2015) in which, indeed, restaurant staff participate. Recent calls from prominent figures, including Allison Hope Alkon (2014), Mark Bittman (2014), and Michael Pollan (2013), to bring attention to and re-emphasize issues of wage labor in the agrifood movement agenda are promising. Scholars also recognize the "transformative potential of agrifood politics" in reframe food system discourse (Fairbairn, 2012, p. 218). However, agrifood movement literature generally represents food system labor through images, descriptions, and depictions of farm workers and other agriculturerelated labor such as slaughtering and meatpacking. Although engaging in a more holistic dialogue that considers the continuum of labor abuse across the food system may be a difficult task, privileging particular representations of food system labor reinforces what Guthman (2014) has called an "agrarian imaginary."

The trope of agrarianism is widely evident in the seminal books of the agrifood movement. For example, while index searches for "work" and "labor" fruitfully turn up reports of labor abuse, as well as critiques of workers compensation insurance practices, labor contractors, and the Fair Labor Standards Act of 1938, these are usually described in terms of farm and agricultural workers, migrant laborers, and (less frequently) those who labor in slaughterhouses (Alkon \& Agyeman, 2011; Gottlieb \& Joshi, 2010; Gray, 2014; Weber, 2009). Perhaps this is a move to promote agricultural work, as it continues to become more precarious under the weight of the very industrial food system that is itself sustained by restaurants peddling mass-produced and processed food. Importantly, the agrarian mythos also constrains that which it purports to signify, sustaining a "mystified image of a redemptive morally righteous family

alternative food movement, and so forth), it is beyond the scope of the present study to pin down what is an increasingly nebulous, expansive, and niche-oriented movement(s), volume of literature, and range of agendas. 
farm" (Besky \& Brown, 2015, p. 25). Representations of idyllic and pastoral family farms do not align with the reality of modern production agriculture, and belie the landholding consolidation, pesticide toxicity, and rural poverty, among other issues, which characterize the reality of modern agriculture.

To be sure, Guthman (2011) and Gottlieb and Joshi (2010) make passing mention of cheap food labor, as well as restaurant and warehouse labor; the former couches this in a historical analysis of farmland dispossession by primitive accumulation, while the latter notes how food chain unions such as ROC and Warehouse Workers United "expand the food justice agenda" (p. xii). Eric Schlosser's influential book Fast Food Nation (2001) remains not only the earliest exposé of the forces that produce and sustain a cheap food-labor force, including fast food workers and meatpackers, but also the single most pioneering bastion of support for industrial wage labor reform.

Such a narrow definition of "conventional food chain workers" (Sbicca, 2015, p. 676) unintentionally and subconsciously "substitutes the actual hierarchical labor-intensive workings of industrial [food]" (Besky \& Brown, 2015, p. 25). with a false hierarchy that privileges agricultural labor while marginalizing the workers who prepare and serve food. The latter, it should be noted, are the food system workers modern consumers are most likely to encounter; the average American consumer dines in restaurants at least once a week (Rassmussen Reports, 2013). The agrifood movement agenda would be better served to engage the interlinked nature of food system labor as it exists—on a continuum of insecurity and inequity. In other words, limiting food system labor to the agrarian sectors forecloses efforts to make the mainstream agrifood movement inclusive, and is simply not responsive to the complex reality of modern food system labor.

Some food and labor studies researchers have raised the centrality of labor to food justice and the simultaneous inability to "stave off worsening labor conditions" (Sbicca, 2015, p. 676) as a key contradiction within the agrifood movement (Besky \& Brown, 2014; Fairbairn, 2012; Sachs, Allen, Terman, Hayden, \& Hatcher, 2014). Through
ROC, activists are actively seeking to redefine food security and food justice in order to account for the exploitative practices of the restaurant industry. \#LivingOffTips offers a platform for sharing server experience working for tips; through their posts, ROC activists stake their position as food system laborers, using stories of wage exploitation to frame their fight for subminimum wage reform and influence all who participate in this wage system.

\section{Strategic Framing and Narratives}

Framing refers to the way communicators strategically construct messages to delimit, characterize or otherwise shape perception of an issue or argument in an effort to influence judgments, attitudes, or behavior (Benford \& Snow, 2000; Entman, 1993; Goffman, 1974; Hallahan, 2008; Kim, 2015). While framing is primarily considered in terms of broadcast media communication strategies (Entman, 1993), social advocates also strategically frame their messages to gain a favorable response (Hallahan, 2008). Framing highlights the process of meaning creation, and is not limited to "skilled" communicators (broadcasters, media, or professionals) but can be strategically deployed by those seeking to influence cognitive or behavioral outcomes.

Frames operate as "schemata of interpretation," or windows of understanding; by focusing attention on particular aspects of social reality, individuals can "locate, perceive, identify, and label" a particular meaning (Goffman, 1974, p. 21). For example, shifting from a violent connotation as in the statement, "She decimated my idea," to one of disagreement as in "Her idea conflicted with mine," affects perception in an event like a public debate. In this way, frames provide what Hallahan (2008) identifies as "contextual cues" (p. 4856) that influence cognitive processing and decisionmaking, shaping not only what to think about, but how to think about situations, issues, and topics. As an interpretive intervention, frames affect how an issue or topic is defined and characterized, as well as how causes and remedies are attributed (Entman, 1993; Hallahan, 2008). Communicative frames can influence decision-making by presenting the "acts, outcomes, and contingencies 
associated with a particular choice" (Kim, 2015, p. 286). For example, campaigns presenting the positive results of behavior shifts are more likely to be persuasive than those depicting deleterious consequences of continued inaction (Kim, 2015).

Communicative frames also aid in agendasetting, playing a critical role in the creation of public discourse about a social problem (Hallahan, 2008, p. 4858). As Benford and Snow (2000) state, social movements actively mobilize meaning and ideas as agents of signification (p. 613). Indeed, social groups, including advocates and activists, must be strategic when framing the issues for which they campaign, as well as the social changes they seek, in order to shift understanding, gain support and forge alliances, and to achieve instrumental gains. For example, Fairbairn (2012) explicates food sovereignty as a counterframe for the corporate food regime, signifying discursive opposition to the structure of the global industrial food system. The food sovereignty movement uses framing to challenge the mainstream and historical meaning of food security, as well as to reconfigure the function of the food system itself. Framing is thus an essential rhetorical tool, which can affect choices involved in responding to, mitigating, or resisting social political issues faced by various audiences.

The story form is widely recognized as a catalyst for effective framing, as it allows communicators to "capitalize on culturally resonating elements" and "make [a topic] attractive" to various audiences (Hallahan, 2008, p. 4859). Narratives are widely recognized for their sense-making capability and persuasive function (Clair et al, 2014; Fisher, 1984; Hammack, 2011). As Fisher (1984) has argued, narratives reinforce beliefs, illuminate cultural beliefs and values, aid in the management of social norms, and even cultivate cultural identity. Indeed, narrative provides a lens for understanding everyday experience, cultural history, and social reality (Clair et al, 2014). The arrangement of information into a plot, ascription of character attributes, definition of causes and outcomes, and depiction of plausible events make narrative a handy and effective interpretative package. Through their form (sequential structure), fidelity (what makes a story "ring true"), and probability (what constitutes a coherent story), narratives inform the "good reasons" used in decisionmaking (Fisher, 1984, p. 7). In this way, narratives do more than just tell stories: they convey meaning and can influence behavior and action.

Importantly, narratives provide an interpretive prism through which "implications for a particular configuration of social categories" can be revealed, examined, and changed (Hammack, 2011, p. 312). Some narratives function specifically to expose structural conditions of inequality; counterstories can empower their writers by providing space in which to reveal, name, and criticize their marginalized status, while making audiences more aware of the need for reform. For example, Dixon (2015) compellingly explicates the power of stories to resist marginalizing master narratives linking hunger with a lack of personal responsibility. By defining situations or issues, explaining causes, and locating remedies or solutions, narratives allow social actors to communicatively frame (unjust) experience, and thus intervene in audience perception, judgement, and action on an issue or cause.

ROC activists communicatively and strategically use their stories to frame the risky nature of tipped labor through appeals based on unstable wages, hazardous working conditions, and the threat of bodily harm. In this way, narratives of restaurant labor exploitation define tips as an issue of wage inequality and emphasize the essential role played by wait staff in the food system, encouraging a reconsideration of food system labor and subminimum wage reform by all those who can affect change in this wage system.

\section{Method and Data Analysis}

The analysis utilizes a qualitative textual-analysis methodology to examine how tipped workers use narratives to frame the conditions of their labor. Text-based research methods allow researchers to gain insights into the nuanced strategies used in public communication to influence perceptions of social issues, define problems, and advocate for solutions. The data for this analysis has been compiled via close textual analysis, or close reading: the "mindful, disciplined reading of an object [a text] with a view toward deeper understanding of its meaning" (Brummett, 2010, p. 25). Through close 
reading, the researcher seeks to apprehend the socially shared meanings, associations, and possible effects that are suggested and supported by words, images, actions, and messages (Brummett, 2010, p. 7). As a method focused on how messages influence public audiences, close textual analysis is well suited for an analysis of stories of tipped labor exploitation.

An inductive analytic approach was used to decontextualize the data and reconstitute it into themes (Lindlof \& Taylor, 2011, p. 243). Close textual analysis supports an inductive approach because it allows the researcher to dissect the symbols within the textual artifacts that comprise the data-set, using theoretical concepts to apprehend how meaning is created via the signification strategies the texts employ (Brummett, 2010, p. 47). Through several sessions of close reading, the \#LivingOffTips posts were manually coded for repeated and frequently used topics, such as sexual harassment. Data was re-read to draw out variations among the dimensions of the categories identified (Lindlof \& Taylor, 2011, p. 252), delineating communicative themes based on framing devices used the online posts.

The analysis is focused on the most recent year of resistance activity, in which ROC has organized high-profile and large-scale campaigns, and during which key instrumental gains have been achieved. ${ }^{3}$ Primary data include public online posts from tipped workers about their experience living on tipped wages. YouTube clips of restaurant workers' public demonstrations during a living-wage campaign, as well as reports on the subminimum wage and restaurant industry conditions from public policy groups, are also utilized as supplemental data.

Through an interactive public webpage on the ROC site, users can upload personal stories of their experiences of the hardship of food service using the hashtag \#LivingOffTips. The \#LivingOffTips

\footnotetext{
${ }^{3}$ For example, "ROC has led and won 13 major [national] campaigns against exploitation in high-profile restaurant companies, organizing more than 400 workers and winning more than US $\$ 7$ million in financial settlements and improvements in workplace policies" (http://rocunited.org/ourwork/workplace-justice/).
}

campaign web page presents a matrix of photos under the banner "Servers are fed up with tips. These are their stories. Please join us." Each photo reveals the user's story with a hyperlink to "Add your Story." Users who choose to submit are asked to include a name, contact information, a photo, and are given the following questions as guidance for telling their story:

What's it like living off tips? How would a stable, livable wage change your life...What's the craziest thing that's happened to you while working in the restaurant industry? Are you supporting a family? How many years have you been in the industry? Have you ever dealt with unwanted sexual behavior from customers, co-workers, or management? (ROC, 2015d)

A total of 108 \#LivingOffTips stories were available as of December 2014, posted to the campaign website (http:// rocunited.org/living-offtips/); 104 included in the set of artifacts examined for this analysis.

It is important to note that all stories posted to this site are publicly available and accessible in perpetuity on the ROC website. Furthermore, this analysis has been completed through an interpretivist qualitative approach that emphasizes reality as socially constructed, culture as contingent, and communication as constitutive (Lindlof \& Taylor, 2011). The stories contributed to the \#LivingOffTips campaign provide rich examples of restaurant worker perspectives on their own labor conditions and daily work experiences. These stories need not be generalizable to the entire population of tipped restaurant staff; the inclusion of these narratives within a nationally recognized wage reform campaign, however, merits attention. Furthermore, while the nature of these posts makes it impossible to verify user status as actual restaurant workers, the thematic patterns discerned via close textual analysis warrant the constitution of a discourse worthy of examination. Finally, because of the sensitive nature of many of these narratives' content (such as accounts of sexual assault and other personal details), all contributors have been given pseudonyms in the analysis that follows. 


\section{\#LivingOffTips: Framing Tipped Labor Exploitation}

Restaurant employees such as hosts, servers/wait staff, and bussers work for a subminimum wage at which they earn nearly 75 percent less than the federal standard; their income is thus expected to be subsidized by customers' tips. As noted above, tipped restaurant workers endure difficult work conditions and little or no opportunity for health benefits or sick days, and are vulnerable to harassment; these conditions are directly connected to their economic exploitation.

ROC activists use narratives to share their personal experiences of earning tips as restaurant wait staff. By framing tipped labor as risky, these narratives define the issue of restaurant labor abuse in terms of wage instability, characterize their working conditions as hazardous, and attribute the threat of bodily harm to the exploitative nature of tipped wages. These stories function to disrupt the social order that largely renders their food service labor invisible, compelling reconsideration of the role these workers play in the food system and illustrating the need for subminimum wage reform.

\section{Wage Instability}

By participating in the \#LivingOffTips campaign, restaurant workers use their stories to name and describe the insecurity of tipped labor in this industry. By framing tips as a gamble-that is, the volatility of not knowing how much (or how little) one will take home each day of work-these stories seek to influence public understanding of how tipped wages work. Indeed, through their stories of personal hardship and financial difficulty, restaurant workers provide a new "schemata of interpretation" (Goffman, 1974, p. 78), that tips are not bonuses for work well done but in fact constitute these workers' main source of income. In this way, \#LivingOffTips narratives illustrate the "outcomes and contingencies” (Kim, 2015, p. 286) associated with tipped labor, contributing to ROC's mission of subminimum wage reform. These stories illustrate how tips function as customer-subsidized wages, with implications for the public who patronize restaurants and contribute to server income as well as for legislators who influence the public policy that determine states subminimum wage level.

Across their posts, restaurant workers describe working for tips as "luck of the draw" (Wendy), a "game of roulette" (Susie), and a "crapshoot every night" (Jackie). These phrases mobilize a risk frame, analogizing their daily work experience to placing a bet on whether and how much income they will make that day. Framing tipped wages in terms of instability denotes the unpredictable nature of earning a wage that is ultimately determined by the customer.

For example, a worker named Page notes that servers cannot anticipate how busy their restaurant or how generous their customers will be, and the effect that has on her income: "Consider this: I earn [US] $\$ 5.83$ an hour before tips... whether we have a busy or slow shift, that won't even get me a trip to and from downtown." Most owners/managers cannot reliably anticipate the day's business, and about a quarter of all restaurants close in their first year due to lack of profitability (Parsa, Self, Nitje, \& King, 2005). Page's story strategically frames two important aspects of \#LivingOffTips. First, she explicitly names the two-tiered wage system by which she is paid, simultaneously indicating the steady, though still inadequate, nature of her hourly wage (she knows she will earn US $\$ 5.83$ per hour for the time worked during her shift) and the variable nature of her tips (dependent as they are on having a "busy or slow shift"). Second, defining her wage in terms of transportation (presumably, gas money or transit fare) exposes how dependent on tips she is and the lack of reliable access to other necessities, such as transport, associated with the unstable nature of tips.

Similarly, another tipped worker named Mindy describes the difficulty she faces raising a family on server wages: "I have to [choose] what is important when I never know what I am going to bring home in tips. Sometimes I have to decide do [we] eat or pay my cell phone bill." Not only do tipped workers struggle with the uncertainty of earning a variable amount of income, their stories demonstrate how restaurant work is also constituted by worry [ing] about whether or not their customers are going to help pay their bills. Framing tips in terms of gambling highlights the risk workers face in not knowing day-to-day how much income they 
will be making. In this way, restaurant workers make visible their precarious position as one of the largest workforces in the U.S., even as they "struggle to survive" (Tosha), and "[make] no living at all" (Barbara) while serving food to others who in turn pay their wage through tips.

Across their stories, workers express their disdain for and embarrassment about being "[f]orced to rely on the kindness of society to live" (Abby), that "it's like begging for money" (Tessa). Customers are described as "the strangers I'm serving and placating" (Jo) whose tips embody "how they are feeling" (Kirsty) — and ideally, their "generosity and courtesy" (Cara) — toward the server's performance. Indeed, studies show that consumers tip to reward service (Lynn, 2014), and out of social obligation or burden (Azar, 2005, 2007).

Tips often function as a reflection of customer evaluation of the service provided rather than as the price of the labor required for food service, and often as evaluation of the server herself. Wait staff can be punished with little to no tips if customers are not fully satisfied. Servers can even be held accountable for things out of their control, such as coupon application and food preparation, as Claire explains: "Say your burger comes out raw, even if I put it in right, Little or no tip. Say, the food takes too long, no tip for me... Oh, wait? you can't use two coupons at one table? No tip for me. Out of crayons? Don't have to-go cups? NO TIP." Stories like Claire's frame tips as "begging for money," which is a strategic intervention in the common cognitive assumptions about the practice of tipping; it is likely that most consumers are not aware that they are in fact subsidizing server income, not simply rewarding a job well done (Azar, 2007; Kenney, 2011; Lynn, 2014).

By naming their experience and giving voice to their economic hardship, restaurant workers' stories function to make their unstable labor conditions visible, and effectively re-frame their wage insecurity in terms of wage practices and inequality. As Liz beseeches in her post: "Do [restaurant workers] not deserve a sense of financial security simply because they deliver your appetizers?" These stories thus unmask the contradictory attitudes about the importance of tips; customers are under the illusion that they are an extra gratuity, but for workers, tips are in fact piece-wages paid for the quantity of labor expended through food service. In this way, server narratives frame the issue of the subminimum wage, setting the agenda for public discourse on the issue of food service labor and tipped wage inequality. These stories highlight the consequences of the subminimum wage by providing "contextual cues" (Hallahan, 2008 , p. 4855) that influence cognitive processing and decision-making related to tips.

\section{Hazardous Conditions: Working While Sick}

\#LivingOffTips stories use the instability of the subminimum wage to frame hazardous work conditions in the restaurant industry, such as the common occurrence of restaurant workers, including servers and kitchen staff, working while ill. In 2011, the Centers for Disease Control and Prevention reported that almost 12 percent of restaurant workers continued to work while suffering from flu symptoms, vomiting, or diarrhea on two or more shifts in the previous year (Sumner et. al, 2011, p. 217). ROC survey data also show that nearly 90 percent of restaurant workers report not receiving paid sick days or health insurance (Jayaraman, 2013, p. 53). By narrativizing their experiences of working while sick, tipped employees raise questions of worker and food safety. Threats to public health—of restaurant staff and their customers-bolster the unpredictable nature of tipped labor, characterizing the essential role food servers play in providing food to others. In this way, \#LivingOffTips narratives destabilize the meaning of the eating-out experience by highlighting the likelihood that restaurant kitchens and dining establishments may not be as pristine and clean as customers expect. If working while sick is an outcome of tipped-wage inequality, subminimum wage reform not only benefits food service workers but consumers as well.

Working while sick is a strong theme across the stories posted to \#LivingOffTips. For example, Tonya reports, "a close friend of mine was actually in labor and was pressured by management to finish her shift before leaving for the hospital." She witnessed "a grill cook who was actually vomiting in the kitchen and then continued to work because 
he was pressured by management to stay and finish his shift." Freda recounts her own "worst experience," working on Valentine's Day "in one of the fanciest restaurants in Philadelphia" while stricken with strep throat, a highly communicable disease and public health hazard. Her manager refused to allow her to go home, thus risking exposure to restaurant staff and consumers, about which she sarcastically remarks, "Would you like Streptococcus with your romance?"

Tipped workers endure what Monica describes as a "tough, physical job that wears on your back, knees, and wrists." In fact, in 2011 the U.S. Department of Labor ranked the restaurant industry as the third highest in total number of nonfatal occupational injuries and illnesses, including minor cuts, burns, slipping and falling (Jayaraman, 2013). Additionally, Jayaraman (2013) argues that the restaurant work environment may actually be making employees ill via exposure to one another, foodborne bacteria, and the fast-paced prep/service environment that often leaves workers unable to properly wash their hands or wear gloves. These conditions neglect the effect of food industry labor on employees' health, and hide how customer health and safety is interconnected with that of the restaurant staff preparing and serving their food.

As Emma notes in her \#LivingOffTips story, "rarely do restaurants create a shift schedule that accounts for the possibility of someone needing a day off at the last minute." Worse yet, Gina describes being pressured by management to find her own replacement if she expects to take a sick day: "[]] was told that it was my responsibility to call all of my coworkers and find someone willing to cover for me, and that if I could not find someone, I would still be expected to come to work." Tipped workers report high rates of threats of termination should they call in sick or ask for a day of rest. Illustrating these conditions through stories reveal how servers and wait staff are treated as a contingent labor force whose members can be easily and quickly replaced by others held in reserve. Because food industry employment requires little formal training, it can easy capitalize on low-skilled labor; restaurant employers can rely on a steady applicant pool waiting to fill employees' spots on the payroll.
Stories of working while sick are compelling because they create a new window of understanding (Goffman, 1974) about the role played by the prep, line, and service staff in securing the smooth operation of a system that provides food for 58 percent of all Americans at least once a week (Rasmussen Reports, 2013). That these hazardous conditions must be endured while earning an unpredictable income means that servers threatened by termination and quick replacement are unduly forced to expend their labor at any cost, risking not only their own health but that of any others exposed to them in the restaurant environment. Servers' stories strategically frame the vulnerability of workers under the subminimum wage system, redefining the relationship between customer and server. In this way, these stories present the deleterious consequences of tipped wage inequality and the implications of the subminimum wage for workers and consumers alike.

\section{Threats of Bodily Harm}

As revealed by their stories, perhaps the most contemptible aspect of the \#LivingOffTips experiences is restaurant workers' vulnerability to sexual harassment, abuse, and even physical assault. ROC data show that the restaurant industry is the single largest source of workplace sexual harassment, with 90 percent of female tipped workers experiencing some form of sexual harassment on the job (ROC \& Forward Together, 2014). Tipped workers often feel pressured to be flirtatious with customers in order to encourage better tips from patrons, but this also exposes them to assault by restaurant owners and staff, leaving them feeling helpless. These worker stories frame sexual abuse as a condition for wages, the stories functioning as an interpretive intervention for those who participate in the subminimum wage system. In this way, \#LivingOffTips narratives make visible another "outcome and contingenc[y]" (Kim, 2015, p. 286) associated with tipped labor, that of workplace safety and gender equity, and demonstrating the significant implications for subminimum wage reform.

Many \#LivingOffTips stories recount pressure for servers and wait staff to flirt and otherwise sexually provoke customers by, for example, dressing 
seductively or leading customers on. For example, Virginia recalls being called “'Bunny' by dirty old men" as well as having to tolerate incessant "comments...about my body and clothes." Furthermore, as Virginia "refused to dress provocatively," she believes this "probably contributed to [her] low tips." Lynn notes, "customers decide how much they'll pay you by what they think of your looks" because "people tip for pretty, sexy, and flirty [waitresses]." Submitting to the reality of these abusive workplace conditions, some servers deliberately manipulate their dress as a means to garner more tips, as Nancy reports: "The girls I worked with and I had what we called a 'tip shirt' or 'tip dress,' something revealing that we made more money when we wore." Trish explains how she "felt a constant pressure to dress and act in ways I didn't always feel total comfortable with. This meant heels, make-up, close-fitting outfits... as a woman I couldn't get tips if I didn't embody a certain appeal."

Natasha, appearing at a ROC-sponsored 1 Fair Wage campaign rally, ${ }^{4}$ explicates the issue in clear terms: "they [customers] think my body is for them to enjoy, look at, touch, say what they want. They think if they throw me a couple of dollars in the form of a tip, it's ok...It's like a power thing." Trish similarly states that "conforming to the sexism of the position meant a certain loss of dignity, but had to do it because I needed to make a living." These workers' stories strategically frame customer-subsidized wages as a grants/exchange protocol between the restaurant worker and her customer, demonstrating the sexual objectification of servers as an outcome of tipping. Though it is not uncommon for restaurants and other dining establishments to encourage staff to "dress to impress," or even require revealing uniforms to lure in a male customer base (Associated Press, 2012; Daley, 2011), these stories of restaurant labor abuse directly attribute employee subjection to unwanted sexual advances to the practice of tipping and the subminimum wage.

Restaurant sexual harassment is not limited to

\footnotetext{
${ }^{4} 1$ Fair Wage works in conjunction with the \#LivingOffTips and \#ImNotontheMenu campaigns organized by ROC (http://rocunited.org/one-fair-wage/).
}

unwanted catcalls and other flirtatious advances from customers; restaurant staff can experience violent sexual assault. Women who work in alcohol-related positions, such as bartending, bar backing, or cocktail waitressing, are more vulnerable to sexual assault on the job (ROC \& Forward Together, 2014). Tina, a so-called "shot girl" at a college sports bar, shares a particularly horrific story of workplace rape. She describes being lured under the guise of "[learning] how we take alcohol inventory." Upon entering a storage unit, she was told, "OK, sweetheart, tour's [sic] over"; her manager began aggressively kissing, touching, and sexually assaulting her. When she complained, he responded, "You are the one that came down here." She left feeling "humiliated, violated, and degraded."

With its graphic detail, Tina's story illustrates the degree of violence that tipped employees may suffer in the restaurant industry. Exploiting managerial authority, and what may also be an age difference, this brutality is more than an occupational hazard. Tina's story frames subminimum health and safety standards in terms of the subminimum wage she earns as a "shot girl."

Tipped workers reluctantly tolerate workplace harassment from both customers and management because, as Nancy put it, "those guys are paying my rent. The management is also often guilty of giving unwanted sexual attention, which is also tolerated, because they decide which shifts I work." By making visible the overt exploitation — and then forced internalization of this exploitation — of servers through sexual abuse, these \#LivingOffTips stories present, in horrific detail, the "acts, outcomes, and contingencies" (Kim, 2015, p. 286) of the subminimum wage.

By narrativizing their experiences at \#LivingOffTips, ROC activists define the unpredictability of tips, characterize their hazardous work conditions, and demonstrate the physical implications of the subminimum wage. Further, I argue, tipped worker framing of the instability and insecurity of their food labor illustrates how wage inequality is experienced across the industrial food system. Researchers and advocates have provided damning evidence of similar sexual abuse among female agricultural workers (Block, 2014; Sachs et 
al., 2014; Longoria \& Schlosser, 2014). Through their use of strategic framing, these restaurant workers are able to make visible the instability of their labor, situate the work they do firmly in the sphere of the food system, and compel consideration of this labor exploitation as an issue relevant to the agrifood movement.

\section{Conclusion}

Heeding the calls of recent food movement figures and researchers (Alkon, 2014; Besky \& Brown, 2015; Bittman, 2014; Pollan, 2013) to attune more closely to issues of wage labor in the food system, this analysis has examined the communicative strategies used by restaurant workers to narrativize and frame their experience as food system workers living off tipped wages. In this way, \#LivingOffTips stories intervene in conventional interpretive schema of tips and/or tipping (as a gratuity or a bonus, not a subsidized wage), the nature of dining establishments (as not pristine, but actual breeding grounds for disease), as well as of servers themselves (vulnerable employees, not sexual objects), all of which are connected to the subminimum wage regime. Framing their experience in this way, and including these stories in the ROC campaign, illustrates the necessity for subminimum wage reform.

The stories posted to the \#LivingOffTips campaign site expose the exploitative nature of working for tips through labeling and narrativizing the direct experience of restaurant workers. Stories of working while sick and experiencing sexual harassment associate the vulnerable bodies of tipped workers with their vulnerable wage situation.

Because tips comprise a higher percentage of these food workers' pay, tipped staff must endure difficult and dangerous conditions to make their income. That most of this is hidden, or ignored, by the average consumer necessitates strategic framing to intervene in common cognitive assumptions about tipping, wait staff, and wages, in order to at once demonstrate the real implications of the subminimum wage as well as influence social change. By posting stories at \#LivingOffTips, these workers make their labor visible to the various audiences that participate in the subminimum wage regime, including the public (who patronize restau- rants), other tipped workers (who may empathize, and thus post their own stories to the site), legislators (who can influence wage policy), and agrifood researchers and advocates (who can shape the discourse of agrifood politics).

This analysis aims to shed light on a hitherto understudied sector of food labor. These stories frame the issues faced by restaurant workers along the same lines as other discourses of food-labor abuse that have garnered much more attention and engagement in the agrifood literature: low wages, difficult work conditions, and vulnerability to abuse. Strategically framing the risks of tipped labor, particularly those associated with their bodies (pressured to work while ill, enduring sexual harassment and assault), restaurant workers demonstrate the role they play in keeping the food system working. That these are also the food system workers whom consumers are the most likely to encounter makes the interpretive intervention their stories seek even more unsettling.

While it need not be an intention of ROC, the 1 Fair Wage campaign, or those who post \#LivingOffTips stories to influence the agrifood movement, their discourse necessarily calls scholars and researchers, advocates and activists, to consider the interconnected nature of food system labor. Although critiques of food system labor have largely been framed through the agrarian imaginary (Guthman, 2014), this latent privileging of farm and agricultural work has had the (likely unintended) consequence of marginalizing other labor abuses endemic to the industrial food system.

Restaurant workers experience poverty and food insecurity at nearly double the rate of any other U.S. workforce (Jayaraman, 2013). Their employment in the food service sector puts this predicament into sharper relief, as they prep and serve food to countless others. Agrifood movement activists, advocates, and researchers must continue to seek out labor exploitation across the food system, and work toward the enactment of labor and wage reforms from farm to table.

\section{Acknowledgments}

The author thanks Dr. Kevin DeLuca and Dr. Danielle Endres, along with the anonymous JAFSCD reviewers, for their support in developing this project. 


\section{References}

Alkon, A. H. (2014). Food justice and the challenge to neoliberalism. Gastronomica, 14(2), 27-40. http://dx.doi.org/10.1525/gfc.2014.14.2.27

Alkon, A. H., \& Agyeman, J. (Eds.). (2011). Cultivating food justice: Race, class, and sustainability. Cambridge, Massachusetts: MIT.

Associated Press. (2012, June 24). Rise of the 'breastaurants': Hooters-like eateries featuring busty women in skimpy tops enjoying booming business. New York Daily News. Retrieved from http://www.nydailynews.com/news/money/risebreastaurants-hooters-like-eateries-featuring-bustywomen-skimpy-tops-enjoying-booming-businessarticle-1.1101527

Azar, O. H. (2005). Who do we tip and why?: An empirical investigation. Applied Economics, 37(16), 1871-1879. http://dx.doi.org/10.1080/00036840500119018

Azar, O. H. (2007). The social norm of tipping: A review. Journal of Applied Social Psychology, 37(2), 380402. http://dx.doi.org/10.2139/ssrn.370081

Benford, R. D., \& Snow, D. A. (2000). Framing processes and social movements: An overview and assessment. Annual Review of Sociology, 26(1), 611639. http://dx.doi.org/10.1146/annurev.soc.26.1.611

Besky, S., \& Brown, S. (2015). Looking for work: Placing labor in food studies. Labor: Studies in Working Class History of the Americas, 12(1-2), 19-43. http://dx.doi.org/10.1215/15476715-2837484

Bittman, M. (2014, June 24). Rethinking the word "foodie." The New York Times. Retrieved from http://www.nytimes.com/2014/06/25/opinion/m ark-bittman-rethinking-the-word-foodie.html?_r=0

Block, S. M. (2014). Invisible survivors: Female farmworkers in the United States and the systematic failure to report workplace harassment and abuse. Texas Journal of Women and the Law, 24, 127-149.

Brummett, B. (2009). Techniques of close reading. Thousand Oaks, California: Sage.

Clair, R. P., Carlo, S., Lam, J. N., Phillips, C., Sánchez, V., Schnabel, E., \& Yakova, L. (2014). Narrative theory and criticism: An overview toward clusters and empathy. The Review of Communication, 14(1), 1-18. http://dx.doi.org/10.1080/15358593. $\underline{2014.925960}$
Coughan, J. (2014, July 28). Restaurants help feed job growth: How the leisure and hospitality industry fared after the recent employment downturn. Washington, D.C.: U.S. Bureau of Labor Statistics. Beyond the Numbers, 3(16). Retrieved from http://www.bls.gov/opub/btn/volume3/restaurants-help-feed-job-growth.htm

Daley, J. (2011, June). 'Breastaurants' ring up big profits. Entrepreneur. Retrieved from http://www.entrepreneur.com/article/219606

Dixon, B. A. (2015). Rewriting the call to charity: From food shelf volunteer to food justice advocate. Journal of Agriculture, Food Systems, and Community Development, 5(2), 71-79. http://dx.doi.org/10.5304/jafscd.2015.052.010

Entman, R. M. (1993). Framing: Toward clarification of a fractured paradigm. Journal of Communication, 43(4), 31-58. http://dx.doi.org/10.1111/j.1460-2466. 1993.tb01304.x

Fairbairn, M. (2012). Framing transformation: The counter-hegemonic potential of food sovereignty in the US context. Agriculture and Human V alues, 29(2), 217-230. http://dx.doi.org/10.1007/s10460-0119334-x

Fisher, W. R. (1984). Narration as human communication paradigm: A case of public moral argument. Communication Monographs, 51(1), 1-22. http://dx.doi.org/10.1080/03637758409390180

Food Chain Workers Alliance (2012). Hands that feed us: Challenges and opportunities for workers along the food chain. Los Angeles: Author. Retrieved from http://foodchainworkers.org/?p=1973

Goffman, E. (1974). Frame analysis: An essay on the organization of experience. Cambridge, Massachusetts: Harvard University Press.

Gottlieb, R., \& Joshi, A. (2010). Food justice. Cambridge, Massachusetts: MIT Press.

Gray, M. (2014). Labor and the locavore: The making of a comprehensive food ethic. Berkeley: University of California Press.

Guthman, J. (2011). Weighing in: Obesity, food justice, and the limits of capitalism. Berkeley: University of California Press.

Guthman, J. (2014). Agrarian dreams: The paradox of organic farming in California (2nd ed.). Oakland: University of California Press. 
Hallahan, K. (2008). Strategic framing. In W. Donsbach (Ed.), The International Encyclopedia of Communication (vol. 10, pp. 4855-4860), Malden, Massachusetts: Blackwell.

Hammack, P. L. (2011). Narrative and the politics of meaning. Narrative Inquiry, 21(2), 311-318. http://dx.doi.org/10.1075/ni.21.2.09ham

Jayaraman, S. (2013). Behind the kitchen door. Ithaca, New York: Cornell University Press.

Kenney, C. (2012). Why we tip [Radio broadcast]. In Planet Money. Washington, D.C.: National Public Radio. Retrieved from http://www.npr.org/ sections/money/2011/06/24/137346289/ why-we-tip

Kim, K. E. (2015). Framing as a strategic persuasive message tactic. In D. Holtzhausen \& A. Zerfass (Eds.), The Routledge Handbook of Strategic Communication (pp. 285-302). New York: Routledge.

Lindlof, T. R., \& Taylor, B. C. (2011). Qualitative communication research methods. (3 $3^{\mathrm{rd}} \mathrm{ed}$.). Thousand Oaks, California: Sage.

Longoria, E., \& Scholosser, E. (Executive Producers), \& Rawal, S. (Director). (2014). Food chains [Motion picture]. U.S.: Illumine Group.

Lynn, M. (2015). Service gratuities and tipping: A motivational framework. Journal of Economic Psychology, 46, 74-88. http://dx.doi.org/10.1016/j.joep.2014.12.002

Parsa, H. G., Self, J. T., Nitje, D., \& King, T. (2205). Why restaurants fail. Cornell Hotel and Restaurant Administration Quarterly, 46(3), 304-322.

Pollan, M. (2013). The most important fight in the struggle for food justice. Berkeley, California: MoveOn.org. Retrieved from http:// front.moveon.org/the-most-importantfight-in-the-struggle-for-food-justice/

Rasmussen Reports. (2013). 58\% eat at a restaurant at least once a week. Asbury Park, New Jersey: Rasmussen Reports. Retrieved from http://www.rasmussenreports.com/public content $\angle$ lifestyle/general lifestyle/july 2013/58 eat at a restaurant at least once a week

Restaurant Opportunities Centers United. (2014). We're \#NotontheMenu. New York: Author. Retrieved from https://www.youtube.com/watch? $\mathrm{v}=$ cPoYdwH9Dgs
Restaurant Opportunities Centers United [ROC] \& Forward Together. (2014). The glass floor: Sexual harassment in the restaurant industry. New York: ROC. Retrieved from http://rocunited.org/theglass-floor-sexual-harassment-in-the-restaurantindustry/

ROC. (2015). Living off tips. New York: ROC.

Retrieved from http://rocunited.org/living-offtips/

Sachs, C., Allen, P., Terman, A. R., Hayden, J., \& Hatcher, C. (2014). Front and back of the house: Socio-spatial inequalities in food work. Agriculture \& Human Values, 31(1), 3-17. http://dx.doi.org/10.1007/s10460-013-9445-7

Sbicca, J. (2015). Food labor, economic inequality, and the imperfect politics of process in the alternative food movement. Agriculture and Human Values, 32(4), 675-687. http://dx.doi.org/10.1007/S10460015-9582-2

Schlosser, E. (2001). Fast food nation: The dark side of the all-American meal. Boston: Houghton Mifflin.

Sumner, S., Brown, L. G., Frick, R., Stone, C., Carpenter, L. R., Bushnell, L., Nicholas, D., Mack, J., Blade, H., Tobin-D’Angelo, M., Everstine, K., \& the Environmental Health Specialists Network Working Group. (2011). Factors associated with food workers working while experiencing vomiting or diarrhea. Journal of Food Protection 74(2), 22152220. http://dx.doi.org/10.4315/0362-028X.JFP10-108

U.S. Department of Agriculture, Economic Research Service. (n.d.). What is agriculture's share of the overall U.S. economy? Retrieved from http://www.ers. usda.gov/data-products/chart-gallery/detail.aspx? chartId $=40037$

U.S. Department of Labor. (n.d.) Subminimum wage. Washington, D.C.: U.S. Author. Retrieved from http://www.dol.gov/dol/topic/wages/subminimu mwage.htm

Weber, K. (Ed.). (2009). Food, Inc.: How industrial food is making us sicker, fatter, and poorer and what you can do about it. New York: Public Affairs. 